\title{
Technisch werkdocument RUBS 1994 : De uitstroom en bestemming van schoolverlaters van het schooljaar 1992-1993
}

\author{
Citation for published version (APA):
}

Smoorenburg, M. S. M., Rutjes, J. J., \& van der Velden, R. K. W. (1995). Technisch werkdocument RUBS 1994 : De uitstroom en bestemming van schoolverlaters van het schooljaar 1992-1993. Researchcentrum voor Onderwijs en Arbeidsmarkt, Faculteit der Economische Wetenschappen. ROA Working Papers No. 4 https://doi.org/10.26481/umarow.1995004

Document status and date:

Published: 01/01/1995

DOI:

10.26481/umarow.1995004

Document Version:

Publisher's PDF, also known as Version of record

\section{Please check the document version of this publication:}

- A submitted manuscript is the version of the article upon submission and before peer-review. There can be important differences between the submitted version and the official published version of record. People interested in the research are advised to contact the author for the final version of the publication, or visit the DOI to the publisher's website.

- The final author version and the galley proof are versions of the publication after peer review.

- The final published version features the final layout of the paper including the volume, issue and page numbers.

Link to publication

\footnotetext{
General rights rights.

- You may freely distribute the URL identifying the publication in the public portal. please follow below link for the End User Agreement:

www.umlib.nl/taverne-license

Take down policy

If you believe that this document breaches copyright please contact us at:

repository@maastrichtuniversity.nl

providing details and we will investigate your claim.
}

Copyright and moral rights for the publications made accessible in the public portal are retained by the authors and/or other copyright owners and it is a condition of accessing publications that users recognise and abide by the legal requirements associated with these

- Users may download and print one copy of any publication from the public portal for the purpose of private study or research.

- You may not further distribute the material or use it for any profit-making activity or commercial gain

If the publication is distributed under the terms of Article $25 \mathrm{fa}$ of the Dutch Copyright Act, indicated by the "Taverne" license above, 
Technisch werkdocument RUBS 1994

de uitstroom en bestemming van schoolverlaters

van het schooljaar 1992-1993

M.S.M. van Smoorenburg*,

J.J. Rutjes", R.K.W. van der Velden*

ROA-W-1995/4

* Researchcentrum voor Onderwijs en Arbeidsmarkt (ROA)

* DESAN Marktonderzoek

Researchcentrum voor Onderwijs en Arbeidsmarkt

Faculteit der Economische Wetenschappen en Bedrijfskunde

Rijksuniversiteit Limburg

Maastricht, september 1995 


\section{CIP-GEGEVENS KONINKLIJKE BIBLIOTHEEK, DEN HAAG}

Smoorenburg, M.S.M. van

Technisch werkdocument RUBS 1994 : de uitstroom en bestemming van schoolverlaters van het schooljaar 1992-1993 / M.S.M. van Smoorenburg, J.J. Rutjes, R.K.W. van der Velden. - Maastricht : Researchcentrum voor Onderwijs en Arbeidsmarkt, Faculteit der Economische Wetenschappen, Rijksuniversiteit Limburg. - Tab. - ([Werkdocument] / Researchcentrum voor Onderwijs en Arbeidsmarkt, ISSN 0922-4645 ; ROA-W-1995/4) Met lit. opg.

ISBN 90-5321-163-2

Trefw.: schoolverlaters. 
Inhoudsopgave

Bladzijde

1 Inleiding 1

2 Organisatie en financiering 3

3 Steekproeftrekking, dekkingsgraad, respons en non-respons $\quad 7$

4 Herweging naar landelijke cijfers 16

5 Wijze van dataverzameling 19

6 De vragenlijst $\quad 20$

7 Variabelen, codering en datacleaning $\quad 21$

8 Tabellen 23 


\section{Inleiding}

Voor $\mathrm{u}$ ligt het technische werkdocument behorende bij het onderzoek "Registratie van de Uitstroom en Bestemming van Schoolverlaters 1994" (RUBS'94). Dit onderzoek had betrekking op de uitstroom van VBO-, KMBO-, MBO-, AVO- en BBO-schoolverlaters van het schooljaar 1992-1993. In dit technische werkdocument is enige ondersteunende informatie verzameld omtrent de vele aspecten van het onderzoek. Zo wordt in hoofdstuk 2 ingegaan op de organisatie en financiering, doet hoofdstuk 3 verslag van de steekproeftrekking, de dekkingsgraad, de respons en de non-respons, bespreekt hoofdstuk 4 de weging, wordt in hoofdstuk 5 de wijze van dataverzameling besproken, bevat hoofdstuk 6 informatie over (wijzigingen in) de vragenlijst, stelt hoofdstuk 7 de wijze van datacleaning aan de orde en rond hoofdstuk 8 af met enkele opmerkingen over de aanmaak van tabellen.

De documenten die betrekking hebben op RUBS'94 kunnen ingedeeld worden in twee categorieën: (1) rapporten die de onderzoeksresultaten weergeven, (2) ondersteunende verslagen. Onder de eerste categorie vallen de volgende rapporten:

a. Smoorenburg, M.S.M van, R.K.W. van der Velden, Schoolverlaters op de arbeidsmarkt, de uitstroom en bestemming van het schooljaar 1992-1993, Researchcentrum voor Onderwijs en Arbeidsmarkt, Uitgave: Landelijk Dienstverlenend Centrum voor Studie- en Beroepskeuzevoorlichting, april 1995;

b. Smoorenburg, M.S.M van, R.K.W. van der Velden, Werken en leren in het leerlingwezen, de positie van het BBO; schooljaar 1992-1993, Researchcentrum voor Onderwijs en Arbeidsmarkt, Uitgave: Landelijk Dienstverlenend Centrum voor Studie- en Beroepskeuzevoorlichting, augustus 1995;

c. De regionale arbeidsmarkt'94: Regio Noord, Oost, Zuid; De regionale arbeidsmarkt'94: Regio: West en grote steden, Researchcentrum voor Onderwijs en Arbeidsmarkt, Uitgave: Landelijk Dienstverlenend Centrum voor Studie- en Beroepskeuzevoorlichting, 1995;

d. Smoorenburg, M.S.M. van, R.K.W. van der Velden, Leertrajecten in het MBO, Researchcentrum voor Onderwijs en Arbeidsmarkt, Uitgave: Stichting Dienstverlenend Centrum voor Studie- en Beroepskeuzevoorlichting, 1995 (nog te verschijnen);

e. Instellingsrapportages RUBS 1994;

f. Smoorenburg, M.S.M. van, R.K.W. van der Velden, congrespaper: Marktpositie van opleidingen in de tijd vergeleken, Researchcentrum voor Onderwijs en Arbeidsmarkt, 1995.

g. Smoorenburg, M.S.M. van, R.K.W. van der Velden, congrespaper: Training en beloning van schoolverlaters, Researchcentrum voor Onderwijs en Arbeidsmarkt, 1995. 
Rapport $a$ is het hoofdrapport van RUBS 1994 met gegevens over de gediplomeerde uitstroom van schoolverlaters van het VBO, het KMBO, het MBO en het AVO. Het bevat geen gegevens over de uitstroom van het Beroeps Begeleidende Onderwijs en evenmin gegevens over ongediplomeerden. De tabellen in rapport a zijn per item gegroepeerd (bijvoorbeeld het bruto uurloon per opleidingscluster, daarna het percentage vast werk per opleidingscluster etc.). Rapport $b$ bevat zowel gegevens over de uitstroom van het $\mathrm{Be}-$ roeps Begeleidend Onderwijs (schoolcomponent van het leerlingwezen) als gegevens over de uitstroom van VBO-ers, KMBO-ers, MBO-ers en AVO-ers die naar het leerlingwezen zijn gegaan. Rapport $c$ en $d$ zijn in tegenstelling tot de rapporten a en b uitsluitend beschrijvend van aard en bevatten hoofdzakelijk tabellen (rapport c) of schema's (rapport d). In rapport $\mathrm{c}$ worden de onderzoeksresultaten niet gegroepeerd naar item maar naar opleidingscluster respectievelijk opleidingsrichting. Van de opleidingsrichting MBO-technisch: elektrotechniek worden bijvoorbeeld alle kerngegevens op een rijtje gezet (werkloosheid, belangrijkste beroepen, percentage vast werk etc.), vervolgens de opleidingsrichting MBO-technisch: werktuigbouwkunde etc. Bovendien worden in rapport $c$ de onderzoeksresultaten uitgesplitst naar landsdeel (Noorden, Oosten, Westen, Zuiden). Rapport d bevat informatie over de leertrajecten van scholieren. Op basis van de informatie over de vooropleiding, de gevolgde opleiding en de vervolgopleiding worden zogenaamde synthetische cohorten gecreëerd, die middels schema's worden weergegeven. Elke school die geparticipeerd heeft in RUBS 1994 krijgt een zogenaamde instellingsrapportage (rapport e1 $\mathrm{t} / \mathrm{m}$ e219). Deze gegevens zijn instellingsspecifiek, maar bevatten daarnaast ook vergelijkbare landelijke cijfers. Deze rapporten zijn vertrouwelijk. De papers $f$ en $g$ hebben een wetenschappelijk karakter en het is de bedoeling dat dit leidt tot publicatie in wetenschappelijke tijdschriften. Naast de genoemde rapporten c.q. papers zal in de toekomst nog op andere manieren gebruik gemaakt gaan worden van de RUBS-data (bijvoorbeeld voor de prognoses, allochtonen in de zorgsector, rapportages over specifieke probleemstellingen, andere papers etc.). Bovendien zijn ook reeds onderzoeksresultaten weergegeven in bijvoorbeeld Uitleg, Didactief en vele dag-, en vakbladen.

Onder de tweede categorie documenten betreffende RUBS 1994 vallen de volgende ondersteunende verslagen:

a. Technisch werkdocument RUBS 1994, Researchcentrum voor Onderwijs en Arbeidsmarkt, 1995;

b. Rutjes, H. Verslag dataverzameling RUBS 1994, DESAN Marktonderzoek, Amsterdam.

c. Kleijnen, T., Verslag data controle en cleaning RUBS 1994, Researchcentrum voor Onderwijs en Arbeidsmarkt, september 1994;

d. Bijlage bij databestand RUBS 1994, Uitstroom uit het schooljaar 1992-1993, Researchcentrum voor Onderwijs en Arbeidsmarkt, 1994;

e. Verslag codering branche en beroep, Researchcentrum voor Onderwijs en Arbeids- 
markt, 1994;

f. Beheers- en gebruiksreglement RUBS 1994, Researchcentrum voor Onderwijs en Arbeidsmarkt, 1994;

g. RUBS en de Wet Persoons Registratie, Researchcentrum voor Onderwijs en Arbeidsmarkt, 1994;

h. Evaluatie instellingsrapportages RUBS 1994, Stichting Landelijk Dienstverlenend Centrum voor Studie- en Beroepskeuzevoorlichting, Leeuwarden, 1994.

Onderhavig verslag a geeft een globaal overzicht van allerlei technische aangelegenheden betreffende RUBS 1994, welke soms nader uitgewerkt worden in andere documenten (bijvoorbeeld verslag $b, c$ of $d$ ). Verslag $c$ bevat een overzicht van de wijze van aanmaak van nieuwe variabelen. Deze ondersteunende verslagen zijn in principe alleen op aanvraag bij het ROA te verkrijgen. Verslag $h$ is bovendien bij het LDC verkrijgbaar en verslag $b$ is bovendien bij DESAN verkrijgbaar.

\section{Organisatie en financiering}

Het RUBS-project (Registratie van Uitstroom en Bestemming van Schoolverlaters) is een jaarlijks terugkerend onderzoek onder schoolverlaters uit de eerste en tweede fase voortgezet onderwijs. Het onderzoek bestaat uit een schriftelijke enquête onder schoolverlaters van het algemeen voortgezet onderwijs (AVO), het voorbereidend beroepsonderwijs (VBO), het kort middelbaar beroepsonderwijs (KMBO) en het middelbaar beroepsonderwijs (MBO) en dit jaar voor het eerst het Beroeps Begeleidend Onderwijs (BBO).

Vanaf 1992 is het Landelijk Dienstverlenend Centrum voor Studie- en Beroepskeuzevoorlichting (LDC) te Leeuwarden betrokken bij het RUBS-project. Deze coördineert het project en treedt op als opdrachtgever namens de landelijke financiers. In 1994 vond financiering plaats vanuit het Centraal Bestuur voor de Arbeidsvoorziening (CBA), het Ministerie van Onderwijs, Cultuur en Wetenschappen, het Ministerie van Landbouw, Natuurbeheer en Visserij en het LDC. Het Researchcentrum voor Onderwijs en Arbeidsmarkt (ROA) en DESAN Marktonderzoek voeren het onderzoek uit. Daarbij voert het ROA de projectleiding en is daarnaast met name verantwoordelijk voor de wetenschappelijke taken in het project (instrumentontwikkeling, steekproefontwerp, databeheer, analyse en rapportage) en organiseert DESAN de dataverzameling en - verwerking.

In 1994 was de opzet van het project als volgt. De landelijk financiering wordt ingezet voor een basissteekproef over de volle breedte van het AVO, VBO en MBO en verspreid over alle regio's. Daarnaast participeren een aantal Adviesbureaus voor Opleiding en Beroep (AOB's) in het project. Door de inbreng van regionale middelen maken zij een 
uitbreiding van de steekproef in hun regio mogelijk. Deze middelen zijn veelal afkomstig van RBA's en provincies. Daarnaast verzorgen AOB's de contacten met de scholen in hun regio. In ruil daarvoor krijgen zij een regionaal databestand op basis waarmee zij aanvullende dienstverlening kunnen opzetten. De volgende AOB's hebben in 1994 additioneel in het onderzoek geparticipeerd:

Tabel 2.1

De RBA-gebieden (Regionaal Bestuur Arbeidsvoorziening) per participerende AOB (Adviesbureau voor Opleiding en Beroep).

\begin{tabular}{ll}
\hline AOB & RBA-Gebied \\
\hline Compaz Groningen & Groningen \\
Compaz Friesland & Friesland \\
Geldergroep & Veluwe \\
& Arnhem / Oost-Gelderland \\
& Nijmegen / Rivierenland \\
Compaz Midden-Nederland & Flevoland \\
& Oost-Utrecht \\
& Midden- en West-Utrecht \\
Octant & 't Gooi \\
& Noord-Holland Noord \\
& Amsterdam / Zaanstreek \\
& Kennemerland / Amstelland \\
AOB Rijnstreek & Rijnstreek \\
AOB Den Haag / Delft & Den Haag / Delft \\
AOB Rijnmond & Rijnmond \\
RDC Limburg & Midden- en Noord-Limburg \\
& Zuid-Limburg \\
\hline
\end{tabular}

De participatie van AOB's wordt verder duidelijk in tabel 2.2 waar per $A O B$ de omvang van de landelijke en additionele meting wordt aangegeven.

De participatie van AOB's kan als volgt toegelicht worden:

\section{a. Groningen}

In verband met het late stadium waarin Groningen actief de onderwijsinstellingen is gaan benaderen is het niet gelukt de landelijke steekproef voor deze regio volledig in te vullen. In Groningen waren echter wel platform gelden beschikbaar op basis waarvan een brede deelname van het MBO in de provincie is gerealiseerd.

b. Friesland

De regio Friesland heeft zich strikt beperkt tot het opvullen van de benodigde aantallen schoolverlaters in het kader van de landelijke steekproef. 


\section{c. Drenthe}

In Drenthe zijn in eerste instantie alle onderwijsinstellingen met een VBO-afdeling aangeschreven voor deelname aan het RUBS-project. In een later stadium zijn hieruit door het $A O B$ de aantallen getrokken welke noodzakelijk waren in het kader van de landelijke steekproef. Bij onderwijsinstellingen heeft dit achteraf tot veel verwarring geleid, omdat men in de veronderstelling verkeerde integraal deel te nemen aan het RUBS-project.

Binnen het MBO heeft het $A O B$ naast RUBS op beperkte schaal ook een instrument genaamd RUBS+ aangeboden. Dit instrument wordt uitgevoerd en verwerkt onder volledige verantwoordelijkheid van het $A O B$ in Drenthe.

\section{d. Gelderland}

Evenals in Groningen heeft het in Gelderland bijzonder lang geduurd alvorens men is gaan participeren en de onderwijsinstellingen heeft benaderd. Op voorhand heeft men aangegeven de intake van de VBO- en AVO-scholen in het kader van de landelijke steekproef liever over te laten aan DESAN. Dit heeft tot gevolg gehad dat Gelderland de enige regio is geweest waar sprake was van een gedeelde verantwoordelijkheid voor de intake. De intake van de MBO- en BBO-scholen is uiteindelijk door Gelderland verzorgd, waarbij additionele gelden beschikbaar waren voor deelname van onderwijsinstellingen in de technische sector.

Naast participatie in de intake heeft Gelderland een deel van de vragenlijsten centraal verzonden.

\section{e. Midden-Nederland}

Midden-Nederland heeft zich in hoofdzaak beperkt tot het vullen van de landelijke steekproef. De regio omvat naast Utrecht ook de provincie Flevoland. In de gehele regio Midden-Nederland is de verzending van de vragenlijsten uitgevoerd vanuit Lelystad.

\section{f. Noord-Holland}

Naast de landelijke steekproef heeft de regio Noord-Holland de onderwijsinstellingen aangeboden op basis van contractgelden te participeren in het RUBS-project 1994. Het feit dat hier niet meer gebruik van gemaakt is heeft alles te maken met de datum waarop het aanbod werd gedaan, te weten januari 1994. Op dat moment hadden met name de meeste kleinere scholen de contractgelden al volledig ingevuld.

Voor een deel van de onderwijsinstellingen heeft Octant de vragenlijsten tegen betaling centraal verzonden. Bij de intake van de onderwijsinstellingen is ondersteuning geboden vanuit DESAN. 


\section{g. Rijnstreek}

In de regio Rijnstreek hebben naast de steekproef scholen op beperkte schaal een aantal onderwijsinstellingen deelgenomen op basis van contractgelden. Rijnstreek heeft deelgenomen op basis van een gezamenlijk contract met Den Haag / Delft en Rijnmond. Voor één onderwijsinstelling heeft Rijnstreek de verzending van de vragenlijsten uitgevoerd.

\section{h. Den Haag / Delft}

Hoewel de regio Den Haag / Delft officieel altijd heeft volgehouden te participeren is er in werkelijkheid nooit iets gebeurd in deze regio qua intake. Dit heeft er toe geleid dat de scholen die zich aangemeld hebben voor deelname binnen de landelijke steekproef achteraf uitermate ongelukkig waren met de verschillende regelingen en de hoeveelheid tijd die men moest investeren.

\section{j. Rijnmond}

In de regio Rijnmond had men de beschikking over gelden van het RBA, welke nog stonden uit 1993. Op basis van deze gelden heeft men een zo integraal mogelijke deelname van het $\mathrm{MBO}$ in de regio nagestreefd. Daarnaast heeft de Gemeente Rotterdam, los van de landelijke steekproef, een meting onder 1.500 VBO-schoolverlaters gefinancierd. Achteraf bleek de gemeente overigens ook behoefte te hebben gehad aan een meting onder AVO-schoolverlaters.

$\mathrm{Na}$ verloop van enige tijd heeft het $A O B$ Rijnmond DESAN verzocht de intake van de onderwijsinstellingen en verdere uitvoering in de regio over te nemen, bij gebrek aan gekwalificeerde mankracht binnen het $A O B$. Overigens is achteraf gebleken dat het AOB toch nog actief is geweest, maar daarvan geen melding heeft gemaakt naar het landelijk niveau. Op deze manier is het mogelijk geweest dat vragenlijsten zijn verzonden zonder de administratieve codes te noteren.

\section{k. Limburg}

Alleen in Zuid-Limburg heeft het RBA in 1994 financieel bijgedragen aan de uitvoering van het RUBS-onderzoek. In deze regio was er dan ook sprake van een brede deelname. In de regio Noord- en Midden Limburg heeft lange tijd onduidelijkheid bestaan over de deelname van de onderwijsinstellingen. Aanvankelijk leken er nog wel mogelijkheden te zijn, maar na verloop van tijd bleek externe financiering niet haalbaar. Op basis van platform gelden van het RDC heeft daarna alsnog een gedeeltelijke ophoging voor de regio plaatsgevonden. Door alle vertraging werden de intake gegevens eerst laat in april 1994 aan DESAN aangeleverd.

Voor een deel van de onderwijsinstellingen heeft het $A O B$ de vragenlijsten tegen betaling centraal verzonden. 
De overige AOB's hebben vooraf aangegeven niet te willen participeren in het RUBSproject 1994 of hebben zich in de loop van het intake-traject teruggetrokken met alle vertraging vandien.

Tabel 2.2

De omvang van de landelijke en additionele meting per AOB.

\begin{tabular}{lrr}
\hline AOB & Landelijk & Additioneel \\
\hline & & \\
Compaz Groningen & 6593 & 364 \\
Compaz Friesland & 812 & 0 \\
Compaz Drente & 720 & 420 \\
Compaz IJsselstreek & 1157 & 0 \\
AOB-Twente & 1022 & 0 \\
Geldergroep & 1950 & 3098 \\
Compaz Midden-Nederland & 1971 & 828 \\
Octant & 2687 & 1301 \\
AOB Rijnstreek & 770 & 1846 \\
AOB Den Haag / Delft & 882 & 134 \\
Compaz Drechtsteden & 788 & 0 \\
AOB Rijnmond & 1098 & 7218 \\
SKOA Zeeland & 1272 & 0 \\
AOB Brabant & 1597 & 0 \\
DOBA / AOB Zuidoost-Brabant & 977 & 0 \\
RDC Limburg & 1790 & 4929 \\
Totaal & 17543 & 16676 \\
& &
\end{tabular}

\section{Steekproeftrekking, dekkingsgraad, respons en non-respons}

De onderzoekspopulatie bestaat uit al diegenen die in Nederland tussen 1 september 1992 en 31 augustus 1993 een opleiding in het lager of middelbaar voortgezet onderwijs hebben verlaten. Hieronder worden gediplomeerde en voortijdige uitstromers van de schooltypen VBO, KMBO, MBO en AVO (MAVO, HAVO, WWO) verstaan. Bovendien zijn in het kader van RUBS 1994 voor het eerst enkele opleidingen in het Beroeps Begeleidend Onderwijs (schoolcomponent van het leerlingwezen) meegenomen. De meting heeft in het voorjaar van 1994 (mei/juni 1994) plaatsgevonden en is derhalve een klein jaar na het verlaten van de opleiding. De duur tussen het verlaten van de opleiding en de deelname aan het onderzoek kan per individu verschillen. Meestal is deze duur 8 tot 12 maanden na het verlaten van de opleiding.

Bij het trekken van de steekproef voor RUBS 1994 is niet uitgegaan van een enkelvoudige aselecte steekproef, maar van een clustersteekproef waarbij opleidingsclusters in scholen (bijvoorbeeld het MBO-technisch in school X) de primaire eenheden vormen en 
waarbij alle elementaire eenheden (i.c. schoolverlaters) binnen deze primaire eenheid benaderd worden ${ }^{1}$. Bij het trekken van de primaire eenheden wordt op basis van populatie- en schoolgegevens reeds rekening gehouden met een evenwichtige en gewenste spreiding naar opleidingscluster, opleidingsrichting, landsdeel en RBA-gebied. Betrekkelijk kleine opleidingsrichtingen, kleinere opleidingsclusters en kleinere regio's kunnen op deze manier enigszins oververtegenwoordigd worden, ten einde ook hiervoor betrouwbare informatie te leveren. Deze steekproeftrekking biedt een garantie voor het kunnen genereren van landelijke representatieve bestemmingsgegevens van schoolverlaters in het $\mathrm{VBO}, \mathrm{KMBO}, \mathrm{MBO}$ en $\mathrm{AVO}$. Bij het $\mathrm{BBO}$ zijn daarentegen enkele dominante opleidingen geselecteerd en heeft geen herweging plaatsgevonden. De onderzoeksresultaten van het BBO zijn daarom niet per se representatief voor het gehele BBO, maar wel voor de onderzochte opleidingen. Op basis van additionele regionale (RBA's, AOB's) en lokale (scholen) wensen, heeft een uitbreiding van het aantal benaderde schoolverlaters plaatsgevonden. Dit biedt mogelijkheden om ook op regionaal c.q. lokaal niveau zinvolle uitspraken te doen en biedt tevens mogelijkheden om op regionaal en lokaal niveau specifieke produkten te leveren. Zonder correctie voor deze regionale en lokale wensen zou dit echter ten koste kunnen gaan van de landelijke representativiteit. Vandaar dat het bestand achteraf teruggewogen is naar landelijke populatiegegevens (zie hoofdstuk 4).

Hoe representatief zijn de uiteindelijk vergaarde en geanalyseerde cases voor de gehele onderzoekspopulatie in Nederland? Deze vraag zal beantwoord worden met behulp van de begrippen dekkingsgraad en responspercentage.

Tabel 3.1 vermeldt cijfers over de dekkingsgraad per opleidingscluster bij gediplomeerde schoolverlaters. Naast deze gediplomeerde schoolverlaters zijn ook nog ruim 7.000 ongediplomeerden benaderd. Omdat hiervan betrouwbare populatiegegevens ontbreken zijn deze bij de berekening van de dekkingsgraad niet betrokken. Onder dekkingsgraad wordt verstaan de verhouding tussen het aantal benaderde schoolverlaters en het totale aantal schoolverlaters in de onderzoekspopulatie. In plaats van bij schoolverlaters kan men ook bij scholen een dekkingspercentage berekenen door de verhouding te nemen tussen het aantal deelnemende scholen en het totale aantal scholen in de onderzoekspopulatie. De dekkingsgraad is een maatstaf voor de mate van vertegenwoordiging van het RUBSonderzoek in de totale onderzoekspopulatie. In totaal hebben 219 scholen deelgenomen aan RUBS 1994. Indien men overigens het aantal deelnemende scholen per opleidings-

1. Janssens, J.M.A.M., Ogen doen onderzoek, Een inleiding in de methoden van sociaalwetenschappelijk onderzoek, Swets \& Zeitlinger B.V., Amsterdam/Lisse, 1991. 
cluster in tabel 3.1 optelt, dan levert dit meer op dan het totaal aantal participerende scholen. Scholen kunnen namelijk met meerdere opleidingsclusters in RUBS deelnemen.

Tabel 3.1

Dekkingsgraad in RUBS 1994 per opleidingscluster bij gediplomeerde schoolverlaters

\begin{tabular}{|c|c|c|c|}
\hline Opleidingscluster & populatie $^{a}$ & deelname & dekkingsgraad \\
\hline \multicolumn{4}{|l|}{ aantal scholen } \\
\hline VBO agrarisch & $112 \mathrm{~b}$ & 12 & $11 \%$ \\
\hline VBO technisch & 355 & 35 & $10 \%$ \\
\hline VBO economisch-administratief & 305 & 41 & $13 \%$ \\
\hline VBO verzorgend & 396 & 55 & $14 \%$ \\
\hline KMBO agrarisch & & 4 & \\
\hline KMBO technisch & $8 \overline{5}$ & 33 & $39 \%$ \\
\hline KMBO economisch-administratief & 80 & 21 & $26 \%$ \\
\hline KMBO verzorgend & 62 & 26 & $42 \%$ \\
\hline MBO agrarisch & $43^{b}$ & 5 & $12 \%$ \\
\hline MBO technisch & 81 & 40 & $49 \%$ \\
\hline MBO economisch-administratief & 82 & 26 & $32 \%$ \\
\hline MBO verzorgend & 77 & 40 & $52 \%$ \\
\hline MAVO & 918 & 31 & $3 \%$ \\
\hline HAVO & 487 & 8 & $2 \%$ \\
\hline VWO & 498 & 8 & $2 \%$ \\
\hline \multicolumn{4}{|l|}{ aantal gediplomeerden } \\
\hline VBO-agrarisch & $3825^{b}$ & 403 & $11 \%$ \\
\hline VBO-technisch & 23751 & 2174 & $9 \%$ \\
\hline VBO-econ.adm. & 10123 & 1677 & $17 \%$ \\
\hline VBO-verzorgend & 11131 & 2045 & $18 \%$ \\
\hline Sub-totaal & 48830 & 6299 & $13 \%$ \\
\hline KMBO-agrarisch & & 135 & \\
\hline KMBO-technisch & $6098^{\bar{c}}$ & 1126 & $18 \%$ \\
\hline KMBO-econ.admin. & $7475^{c}$ & 969 & $13 \%$ \\
\hline KMBO-verzorgend & $1876^{c}$ & 548 & $29 \%$ \\
\hline Sub-totaal & 15449 & 2778 & $17 \%$ \\
\hline MBO-agrarisch & $2681^{b}$ & 310 & $12 \%$ \\
\hline MBO-technisch & $17283^{d}$ & 6174 & $36 \%$ \\
\hline MBO-econ.admin. & $21203^{d}$ & 4715 & $22 \%$ \\
\hline MBO-verzorgend & $14723^{d}$ & 6774 & $46 \%$ \\
\hline Sub-totaal & 55890 & 17973 & $32 \%$ \\
\hline
\end{tabular}


Tabel 3.1 (vervolg)

Dekkingsgraad in RUBS 1994 per opleidingscluster bij gediplomeerde schoolverlaters

\begin{tabular}{lccc}
\hline Opleidingscluster & populatie $^{\text {a }}$ & deelname & dekkingsgraad \\
\hline MAVO & $54665^{\mathrm{d}}$ & 1686 & $3 \%$ \\
HAVO & $34633^{\mathrm{d}}$ & 377 & $1 \%$ \\
WWO & $30288^{\mathrm{d}}$ & 500 & $2 \%$ \\
Sub-totaal & $119586^{-}$ & 2563 & $2 \%$ \\
BBO-technisch & $17195^{\text {e,f }}$ & 1398 & $8 \%$ \\
BBO-econ.admin. & $3397^{\text {e,g }}$ & 735 & $22 \%$ \\
BBO-verzorgend & $3380^{\text {e,h }}$ & 432 & $13 \%$ \\
Sub-totaal & $23972^{-}$ & 2565 & $11 \%$ \\
TOTAAL & 263727 & 32043 & $12 \%$ \\
\end{tabular}

a Bron: Integrale Leerlingtelling (ILT) van 1993, Ministerie van Onderwijs, Cultuur en Wetenschappen. Bij de leerlingaantallen betreft het een totaal aantal gediplomeerden volgens de RUBS opleidingscodering.

b Bron: Ministerie van Landbouw, Natuurbeheer en Visserij. Bij het VBO-agrarisch zijn bij de gediplomeerden een geschat aantal IVBO-ers in mindering gebracht.

c Dit aantal betreft het totaal aantal leerlingen in het $2^{\mathrm{e}}$ jaar van het KMBO

d Het aantal gediplomeerden (op basis van de ILT van 1993) is opgehoogd met een geschat aantal deelcertificaathouders en gediplomeerden met uitsluitend een theorie-examen.

e Bron: Opgave van het leerlingwezen (OVL) van 1993, Ministerie van Onderwijs, Cultuur en Wetenschappen. De uitstroom van de primaire opleidingen van het Beroeps Begeleidend Onderwijs is berekend door het aantal scholieren te delen door de gemiddelde verblijfsduur per vakrichting. Deze gemiddelde verblijfsduur per vakrichting is overgenomen uit het rapport "Toekomstverkenning leerlingwezen, ROA-R-1993/4).

f. De volgende primaire opleidingsrichtingen in het BBO-technisch zijn geselecteerd voor de steekproeftrekking: Bouwtechniek, Metaaltechniek I, Metaaltechniek II, Metaaltechniek III, Motorvoertuigentechniek, Elektrotechniek, Installatietechniek, Verfapplicatietechniek, Consumptieve techniek.

g. De volgende primaire opleidingsrichtingen in het BBO-economisch-administratief zijn geselecteerd voor de steekproeftrekking: Detailhandel, economische \& administratieve beroepen.

h. De volgende primaire opleidingsrichtingen in het BBO-verzorgend zijn geselecteerd voor de steekproeftrekking: Verzorgende \& dienstverlenende beroepen, haarkappen.

Uit tabel 3.1 blijkt dat voor de totale onderzoekspopulatie een dekkingspercentage van $12 \%$ is bereikt. Dit wil zeggen zo'n één op de acht personen die in het schooljaar 1992/1993 hun opleiding in het VBO, MBO, KMBO, MAVO, HAVO, VWO, BBO gediplomeerd hebben verlaten, zijn in het voorjaar van 1994 in het kader van RUBS benaderd. De dekkingspercentages en absolute aantallen benaderde schoolverlaters variëren sterk per opleidingscluster, waaraan een tweetal hoofdredenen ten grondslag liggen.

Allereerst zijn er enkele steekproeftechnische redenen. Om betrouwbare uitspraken te 
kunnen doen over een opleidingsrichting is een bepaald minimum aantal schoolverlaters vereist (de grens wordt in dit RUBS-onderzoek op 25 personen gesteld). Indien er weinig verschillende opleidingsrichtingen in een opleidingscluster vallen (bijvoorbeeld bij het AVO en KMBO) dan kunnen de absolute aantallen op clusterniveau ook beperkt blijven. Bovendien is het zo dat bij een klein percentage schoolverlaters dat de arbeidsmarkt betreedt het absolute aantal benaderde schoolverlaters hoger zal moeten zijn (AVO), ten einde ook over deze groep uitspraken te kunnen doen. Verder speelt het verwachte responspercentage een rol en zal daardoor soms het te benaderen aantal schoolverlaters opgehoogd moeten worden.

Als tweede hoofdreden geldt dat een hoger absoluut aantal benaderde schoolverlaters voor een bepaald opleidingscluster het gevolg kan zijn van additionele metingen bij het desbetreffende opleidingscluster. Dit heeft vooral bij het MBO een rol gespeeld. Bij het HAVO en het VWO moet nog gemeld worden dat deze opleidingsclusters niet in de basissteekproef zijn betrokken. Dat er desondanks vragenlijsten zijn uitgezet bij HAVO- en VWO-schoolverlaters is toe te schrijven aan de additionele meting. De dekkingspercentages behorende bij het aantal scholen wijken overigens nauwelijks af van de dekkingspercentages uitgedrukt in aantal gediplomeerden, wellicht met uitzondering van het KMBO. Kennelijk zijn in RUBS bij het KMBO kleine scholen enigszins oververtegenwoordigd. Samenvattend kan gesteld worden dat in zijn totaliteit een dekkingsgraad bereikt is van $12 \%$ van de gediplomeerden, dat sommige opleidingsclusters (bijvoorbeeld $\mathrm{MBO}$ verzorgend, $\mathrm{MBO}$-technisch, $\mathrm{KMBO}$-verzorgend) omvangrijker vertegenwoordigd zijn dan anderen (AVO, BBO-technisch, VBO-technisch) en dat dit enerzijds te maken heeft met een efficiënte steekproeftrekking en anderzijds met additionele metingen.

\section{Respons en non-respons}

Niet alleen dekkingspercentages maar ook responspercentages bepalen het uiteindelijke aantal responderende schoolverlaters. Voor wat betreft de aantallen gediplomeerde schoolverlaters komt de middelste kolom van tabel 3.1 overeen met de linkerkolom van tabel 3.2. In totaal zijn er binnen de schooltypen VBO, KMBO, MBO, AVO en BBO 39.277 schoolverlaters benaderd (waarvan 32.043 gediplomeerden), hetgeen geresulteerd heeft in een respons van 16.936 personen (43\%). Bij de gediplomeerden is het algehele responspercentage $48 \%$, met het hoogste responspercentage in het AVO-onderwijs $(60 \%)$, gevolgd door het MBO (51\%), het VBO (46\%), het KMBO $(41 \%)$ en tot slot het BBO (21\%). In RUBS 1993 bedroeg het algehele responspercentage bij gediplomeerden 65\%, met het hoogste responspercentage in het AVO-onderwijs (71\%), gevolgd door het MBO $(66 \%)$, het VBO $(60 \%)$ en het KMBO $(52 \%)$. 
$\mathrm{Er}$ is een aantal oorzaken aan te wijzen voor de lagere respons. Allereerst ligt een oorzaak voor het lagere, totale responspercentage bij de komst van het BBO en het deels verdwijnen van het AVO in het RUBS-onderzoek. Het eerste schooltype brengt een laag responspercentage met zich mee en het tweede schooltype brengt juist een hoog responspercentage met zich mee, zodat beide feiten in het nadeel van het totale responspercentage hebben gewerkt. Als we het BBO en het AVO buiten beschouwing zouden laten, dan is het responspercentage van gediplomeerde schoolverlaters tussen RUBS 1993 en RUBS 1994 gedaald van 63\% tot 49\%. Ondanks dit schooltype-effect (de responspercentages zijn niet gewogen naar landelijk representatieve gegevens) resteert voor elk schooltype een afname in het responspercentage. Dit kan deels te maken hebben met de meer evenwichtige verdeling naar landsdeel ten opzichte van RUBS 1993. Vorig jaar was Zuid-Nederland sterk oververtegenwoordigd en West-Nederland sterk ondervertegenwoordigd hetgeen gepaard ging met een hogere respons. Door de evenwichtige verdeling naar landsdeel is in RUBS 1994 dit "responsvoordeel" verdwenen.

Desalniettemin verklaren deze beide oorzaken niet de gehele daling in het responspercentage. Verder zou een rol kunnen hebben gespeeld, dat de uitvoering van het onderzoek laat van start is gegaan. Hierdoor hebben zowel de AOB's die voor een deel centrale verzending verzorgden als de onderwijsinstellingen in vele gevallen de vragenlijsten in een zeer laat stadium de deur uit gedaan. Afgezien van het feit dat als gevolg hiervan in een aantal gevallen het rappel niet meer verzonden is, viel het rappel voor een deel van de regio's samen met de start van de zomervakantie. Daarnaast is met ingang van RUBS'94 voor het eerst gevraagd naar de naam, adres en woonplaats van de respondent. Ook dit kan de respons negatief hebben beïnvloed. Voor de lage respons van het $\mathrm{BBO}$ gelden daarnaast nog de volgende oorzaken:

a. De instroom in het BBO heeft qua niveau voornamelijk te maken met de doorstroom vanaf het VBO B-niveau. Het is reeds gebleken dat uitvoering van het reguliere RUBS-onderzoek op dit niveau ook niet probleemloos verloopt. Op dit moment wordt door het ROA een onderzoek uitgevoerd naar de meest ideale wijze waarop IVBOschoolverlaters in het onderzoek betrokken zouden kunnen worden.

b. Vooraf is onderschat wat de mogelijkheden zijn van de Streekscholen in termen van administratie. Het is gebleken dat men heel vaak niet beschikte over de (meest recente) adressen van de schoolverlaters. Dit gevoegd bij het feit dat het schooltype geen ervaring heeft met de uitvoering van RUBS heeft er zelfs toe geleid dat op een groot aantal scholen de vragenlijsten in het geheel niet verzonden zijn.

c. De wijze waarop het Ministerie van OCW de leerlingwezen opleidingen benoemt (derhalve de wijze waarop de school dit doet) komt niet overeen met de nomenclatuur die gehanteerd wordt door de landelijke organen voor het leerlingwezen. Dit heeft er toe geleid dat de schoolverlaters zich dikwijls niet hebben herkend in de opleiding die op de vragenlijst werd genoemd. Ook dit kan hebben 
bijgedragen tot een lagere respons.

Tabel 3.2

Respons per opleidingscluster

\begin{tabular}{|c|c|c|c|c|}
\hline \multicolumn{2}{|c|}{ Opleidingscluster } & uitgezet & respons & $\begin{array}{l}\text { respons } \\
\text { percentage }\end{array}$ \\
\hline VBO & GEDIPLOMEERD & 6570 & 2993 & $46 \%$ \\
\hline \multirow[t]{5}{*}{ w.v. } & agrarisch & 403 & 198 & $49 \%$ \\
\hline & technisch & 2174 & 890 & $41 \%$ \\
\hline & economisch-administratief & 1677 & 784 & $47 \%$ \\
\hline & verzorgend & 2045 & 1034 & $51 \%$ \\
\hline & overig & 271 & 87 & $32 \%$ \\
\hline VBO & ONGEDIPLOMEERD & 753 & 181 & $24 \%$ \\
\hline KMBO & GEDIPLOMEERD & 2861 & 1186 & $41 \%$ \\
\hline \multirow[t]{5}{*}{ w.v. } & agrarisch & 135 & 65 & $48 \%$ \\
\hline & technisch & 1126 & 448 & $40 \%$ \\
\hline & economisch-administratief & 969 & 411 & $42 \%$ \\
\hline & verzorgend & 548 & 238 & $43 \%$ \\
\hline & overig & 83 & 24 & $29 \%$ \\
\hline KMBO & ONGEDIPLOMEERD & 944 & 128 & $14 \%$ \\
\hline MBO & GEDIPLOMEERD & 18825 & 9620 & $51 \%$ \\
\hline \multirow[t]{5}{*}{ w.v. } & agrarisch & 310 & 151 & $49 \%$ \\
\hline & technisch & 6174 & 2984 & $48 \%$ \\
\hline & economisch-administratief & 4715 & 2432 & $52 \%$ \\
\hline & verzorgend & 6774 & 3780 & $56 \%$ \\
\hline & overig & 852 & 273 & $32 \%$ \\
\hline MBO & ONGEDIPLOMEERD & 3356 & 604 & $18 \%$ \\
\hline AVO & GEDIPLOMEERD & 2563 & 1528 & $60 \%$ \\
\hline \multirow[t]{3}{*}{ w.v. } & MAVO & 1686 & 1003 & $59 \%$ \\
\hline & HAVO & 377 & 217 & $58 \%$ \\
\hline & VWO & 500 & 308 & $62 \%$ \\
\hline AVO & ONGEDIPLOMEERD & 261 & 52 & $20 \%$ \\
\hline BBO & GEDIPLOMEERD & 2565 & 546 & $21 \%$ \\
\hline \multirow[t]{3}{*}{ w.v. } & technisch & 1398 & 281 & $20 \%$ \\
\hline & econ. adm. & 735 & 127 & $17 \%$ \\
\hline & verzorgend & 432 & 138 & $32 \%$ \\
\hline \multirow[t]{2}{*}{ BBO } & ONGEDIPLOMEERD & 579 & 98 & $17 \%$ \\
\hline & TOTAAL & 39277 & 16936 & $43 \%$ \\
\hline
\end{tabular}

De verschillen in responspercentage tussen gediplomeerden en ongediplomeerden zijn net als voorgaande jaren niet alleen significant maar ook nog eens zeer omvangrijk. Het responspercentage bij gediplomeerden bedraagt namelijk $48 \%$ terwijl het responspercentage bij ongediplomeerden $18 \%$ is. Hiervoor is een aantal redenen te noemen. Allereerst gaat het om de uitstroom van een opleiding; indien een scholier binnen een school van 
opleiding(srichting) is veranderd, wordt hij/zij in de steekproefopzet van RUBS als verlater van een opleiding beschouwd, maar hij/zij zal zichzelf niet als zodanig beschouwen. Daarnaast is de onderzoekspopulatie afgebakend voor een bepaald schooljaar; indien (K)MBO-scholieren niet of nauwelijks zijn begonnen met hun studie en de opleiding spoedig verlaten, wordt hij/zij in de steekproefopzet als verlater van een opleiding beschouwd, maar hij/zij zal zichzelf niet als zodanig beschouwen of zal geen binding met de opleiding hebben. Als derde oorzaak kan het zo zijn dat een scholier verhuist, maar elders dezelfde opleiding gaat volgen; deze scholieren worden ook als verlaters van een opleiding beschouwd, omdat 'technisch' gezien het onderscheid met 'reguliere' voortijdige schoolverlaters niet valt te maken.

Om te onderzoeken of er sprake is van selectiviteit in de antwoorden is een non-responsonderzoek uitgevoerd. Zoals eerder vermeld is de voornaamste doelstelling van RUBS het in kaart brengen van de (eerste) bestemming van schoolverlaters. Vandaar dat door middel van een telefonische enquête 199 personen zijn benaderd met een identieke vraag over de bestemming, die in een eerdere fase niet gerespondeerd hadden. Bij deze nonrespons groep is informatie vergaard over de opleidingsrichting, het diplomabezit, het geslacht, de regionale herkomst en de voornaamste bezigheid op het moment dat het reguliere onderzoek werd uitgevoerd (twee maanden retrospectief). Het non-responsonderzoek is dus veel kleinschaliger dan het reguliere onderzoek maar bestrijkt wel de meeste opleidingsclusters namelijk het VBO-technisch, het VBO-economisch-administratief, het VBO-verzorgend, het KMBO-technisch, het KMBO-verzorgend, het MBO-technisch, het MBO-economisch-administratief, het MBO-verzorgend en het BBO-technisch. Om er zeker van te zijn dat eventuele verschillen in bestemming tussen non-responsgroep en responsgroep niet te wijten zijn aan verschillen in verdeling over de opleidingsclusters, heeft een herweging plaatsgevonden, waarbij het non-responsbestand als uitgangspunt genomen is. Dit is apart voor zowel de gediplomeerden als de ongediplomeerden gebeurd.

De resultaten van de vergelijking tussen de non-responsgroep (157 gediplomeerden en 42 ongediplomeerden) en de vergelijkbare responsgroep (12.802 gediplomeerden en 631 ongediplomeerden) staan in tabel 3.3 vermeld. Bij de gediplomeerden is er geen enkel significant verschil aangetoond tussen de responsgroep en non-responsgroep, met andere woorden de nulhypothese van geen verschil tussen beide groepen is niet verworpen. De in tabel 3.3 opgenomen verschillen tussen responsgroep en non-responsgroep zouden net zo goed op toeval kunnen berusten. Dit is uiteraard een gunstig resultaat omdat het non-responsonderzoek dus uitgewezen heeft dat er bij de bestemming geen sprake is van selectiviteit in de non-respons. 
Tabel 3.3

Verdeling bestemming respons en non-respons groep

\begin{tabular}{lrc}
\hline Bestemming & respons groep & non-respons groep \\
\hline gediplomeerden & & \\
Betaalde baan & $36 \%$ & $33 \%$ \\
Leerlingwezen/in-service & $17 \%$ & $19 \%$ \\
Werkloos & $5 \%$ & $3 \%$ \\
Dagopleiding & $36 \%$ & $36 \%$ \\
Militaire dienst & $6 \%$ & $6 \%$ \\
Anders & $1 \%$ & $3 \%$ \\
& & \\
Totaal (N = 100\%) & 12802 & 157 \\
& & \\
ongediplomeerden & & \\
Betaalde baan & & $55 \% *$ \\
Leerlingwezen/in-service & $38 \%$ & $7 \%$ \\
Werkloos & $12 \%$ & $5 \%$ \\
Dagopleiding & $10 \%$ & $24 \%$ \\
Militaire Dienst & $33 \%$ & $5 \%$ \\
Anders & $4 \%$ & $5 \%$ \\
Totaal (N = 100\%) & $3 \%$ & 42 \\
*: significant verschil, $\mathrm{p}<0,05$ & 631 & \\
& & \\
\end{tabular}

Bij de ongediplomeerden zijn de verschillen tussen responsgroep en non-responsgroep duidelijk omvangrijker dan bij de gediplomeerden. Zo heeft in de non-responsgroep een significant groter gedeelte als voornaamste bezigheid 'betaald werk' opgegeven. Dus in het RUBS'94-bestand zou er sprake kunnen zijn van een onderschatting van het gedeelte ongediplomeerde schoolverlaters dat betaald werk heeft. Het non-respons onderzoek van RUBS'93 liet ook al zien dat niet-responderende ongediplomeerde schoolverlaters minder vaak een voltijds vervolgopleiding volgen en vaker (ofschoon niet significant) een betaalde baan hebben. Bij de groep ongediplomeerde schoolverlaters kan dus niet dezelfde betrouwbaarheid van de bestemmingsgegevens worden gegarandeerd als bij de gediplomeerde schoolverlaters en is er wellicht sprake van een systematische onderschatting van het gedeelte ongediplomeerde schoolverlaters dat een betaalde baan heeft. De overige verschillen tussen de respons-groep en de non-responsgroep zijn niet significant en zouden ook op toeval kunnen duiden. Ter afsluiting valt nog op te merken dat er geen reden is om aan te nemen dat de verdeling binnen een bepaalde bestemming (bijvoorbeeld vervolgopleiding HBO-technisch in plaats van HBO-agrarisch, meer activiteitenbegeleiders en minder timmermannen) vertekend zal zijn. 


\section{Herweging naar landelijke cijfers}

Zoals in hoofdstuk 3 is toegelicht kan als gevolg van de wijze van steekproeftrekking en als gevolg van de mogelijkheden om additionele metingen te verrichten een ongelijke spreiding naar opleiding en regio optreden. Derhalve moet het gehele onderzoeksbestand naderhand teruggewogen worden naar de landelijke verdeling.

Tabel 4.1

Aantallen schoolverlaters per opleidingscluster in het ongewogen bestand

\begin{tabular}{|c|c|c|c|c|c|c|}
\hline \multirow{2}{*}{\multicolumn{2}{|c|}{ Opleidingscluster }} & \multirow[b]{2}{*}{ Noord } & \multicolumn{2}{|c|}{ ONGEWOGEN } & \multirow[b]{2}{*}{ Zuid } & \multirow[b]{2}{*}{ Totaal } \\
\hline & & & Oost & West & & \\
\hline VBO & GEDIPLOMEERD & 332 & 471 & 1347 & 843 & 2993 \\
\hline \multirow[t]{5}{*}{ w.v. } & agrarisch & 21 & 71 & 41 & 65 & 198 \\
\hline & technisch & 73 & 100 & 538 & 179 & 890 \\
\hline & econ.-admin. & 47 & 165 & 301 & 271 & 784 \\
\hline & verzorgend & 117 & 135 & 467 & 315 & 1034 \\
\hline & overig & 74 & 0 & 0 & 13 & 87 \\
\hline VBO & ONGEDIPLOMEERD & 18 & 26 & 87 & 50 & 181 \\
\hline KMBO & GEDIPLOMEERD & 323 & 220 & 301 & 342 & 1186 \\
\hline \multirow[t]{5}{*}{ w.v. } & agrarisch & 0 & 30 & 15 & 20 & 65 \\
\hline & technisch & 137 & 85 & 80 & 146 & 448 \\
\hline & econ.-admin. & 116 & 30 & 164 & 101 & 411 \\
\hline & verzorgend & 68 & 75 & 42 & 53 & 238 \\
\hline & overig & 2 & 0 & 0 & 22 & 24 \\
\hline KMBO & ONGEDIPLOMEERD & 36 & 23 & 30 & 39 & 128 \\
\hline MBO & GEDIPLOMEERD & 1667 & 1995 & 3757 & 2201 & $` 9620$ \\
\hline \multirow{5}{*}{ w.v. } & agrarisch & 0 & 67 & 35 & 49 & 151 \\
\hline & technisch & 472 & 616 & 1225 & 671 & 2984 \\
\hline & econ.-admin. & 432 & 304 & 943 & 753 & 2432 \\
\hline & verzorgend & 745 & 1000 & 1357 & 678 & 3780 \\
\hline & overig & 18 & 8 & 197 & 50 & 273 \\
\hline MBO & ONGEDIPLOMEERD & 85 & 104 & 273 & 142 & 604 \\
\hline AVO & GEDIPLOMEERD & 171 & 226 & 423 & 708 & 1528 \\
\hline \multirow[t]{3}{*}{ w.v. } & MAVO & 171 & 165 & 327 & 340 & 1003 \\
\hline & HAVO & 0 & 47 & 17 & 153 & 217 \\
\hline & VWO & 0 & 14 & 79 & 215 & 308 \\
\hline AVO & ONGEDIPLOMEERD & 4 & 12 & 24 & 12 & 52 \\
\hline BBO & GEDIPLOMEERD & 0 & 129 & 275 & 142 & 546 \\
\hline \multirow[t]{3}{*}{ w.v. } & technisch & 0 & 129 & 72 & 80 & 281 \\
\hline & econ. adm. & 0 & 0 & 72 & 55 & 127 \\
\hline & verzorgend & 0 & 0 & 131 & 7 & 138 \\
\hline BBO & ONGEDIPLOMEERD & 0 & 34 & 49 & 15 & 98 \\
\hline \multicolumn{2}{|c|}{ TOTAAL } & 2636 & 3240 & 6566 & 4494 & 16936 \\
\hline
\end{tabular}


Tabel 4.2

Aantallen schoolverlaters per opleidingscluster in het gewogen bestand.

\begin{tabular}{|c|c|c|c|c|c|c|}
\hline & & & GEN & & & \\
\hline Opleidir & gscluster & Noord & Oost & West & Zuid & Totaal \\
\hline VBO & GEDIPLOMEERD & 387 & 611 & 1758 & 389 & 3145 \\
\hline w.v. & agrarisch & 29 & 111 & 61 & 35 & 237 \\
\hline & technisch & 136 & 212 & 994 & 127 & 1469 \\
\hline & econ.-admin. & 47 & 185 & 322 & 110 & 663 \\
\hline & verzorgend & 101 & 103 & 381 & 104 & 689 \\
\hline & overig & 74 & 0 & 0 & 13 & 87 \\
\hline VBO & ONGEDIPLOMEERD & 18 & 26 & 87 & 50 & 181 \\
\hline KMBO & GEDIPLOMEERD & 324 & 211 & 339 & 170 & 1045 \\
\hline w.v. & agrarisch & 0 & 30 & 15 & 20 & 65 \\
\hline & technisch & 140 & 99 & 78 & 60 & 377 \\
\hline & econ.-admin. & 150 & 42 & 219 & 52 & 463 \\
\hline & verzorgend & 32 & 40 & 27 & 16 & 116 \\
\hline & overig & 2 & 0 & 0 & 22 & 24 \\
\hline KMBO & ONGEDIPLOMEERD & 36 & 23 & 30 & 39 & 128 \\
\hline MBO & GEDIPLOMEERD & 736 & 852 & 1722 & 432 & 3741 \\
\hline w.v. & agrarisch & 0 & 95 & 47 & 24 & 166 \\
\hline & technisch & 227 & 258 & 521 & 126 & 1131 \\
\hline & econ.-admin. & 258 & 206 & 608 & 175 & 1247 \\
\hline & verzorgend & 240 & 287 & 414 & 95 & 1035 \\
\hline & overig & 11 & 6 & 132 & 12 & 162 \\
\hline MBO & ONGEDIPLOMEERD & 85 & 104 & 273 & 142 & 604 \\
\hline AVO & GEDIPLOMEERD & 690 & 1299 & 2056 & 3352 & 7397 \\
\hline w.v. & MAVO & 690 & 750 & 1408 & 534 & 3382 \\
\hline & HAVO & 0 & 464 & 168 & 1510 & 2142 \\
\hline & WWO & 0 & 85 & 480 & 1308 & 1873 \\
\hline AVO & ONGEDIPLOMEERD & 4 & 12 & 24 & 12 & 52 \\
\hline BBO & GEDIPLOMEERD & 0 & 129 & 275 & 142 & 546 \\
\hline w.v. & technisch & 0 & 129 & 72 & 80 & 281 \\
\hline & econ. adm. & 0 & 0 & 72 & 55 & 127 \\
\hline & verzorgend & 0 & 0 & 131 & 7 & 138 \\
\hline BBO & ONGEDIPLOMEERD & 0 & 34 & 49 & 15 & 98 \\
\hline TOTAA & & 2279 & 3300 & 6613 & 4743 & 16936 \\
\hline
\end{tabular}

Voor deze herweging is mede gebruik gemaakt van de Integrale Leerlingtelling (ILT). De ILT is een telling van het aantal leerlingen en het aantal gediplomeerden in het voortgezet (voltijd) onderwijs, voor zover dat door het Ministerie van Onderwijs, Cultuur en Wetenschappen wordt gefinancierd. De ILT bevat slechts sporadische gegevens over het lager en middelbaar agrarisch onderwijs. Derhalve is voor de herweging van deze opleidingsclusters (VBO-agrarisch, KMBO-agrarisch, MBO-agrarisch) gebruik gemaakt van gege- 
vens van het Ministerie van Landbouw, Natuurbeheer en Visserij.

Allereerst is op basis van het RUBS-bestand gekeken naar de verdeling van het aantal schoolverlaters naar opleidingsrichting en landsdeel ${ }^{2}$. De verdeling van het aantal schoolverlaters naar opleidingscluster en landsdeel staat in tabel 4.1 afgebeeld (ongewogen). Vervolgens zijn op basis van bovengenoemde databronnen de populatietotalen per opleidingsrichting en per landsdeel bepaald. De randtotalen van de populatieverdeling van opleidingrichting en landsdeel worden daarna zodanig met een factor vermenigvuldigd dat het totaal aantal schoolverlaters gelijk is aan het totaal aantal schoolverlaters in het RUBS-project. De randtotalen van zowel populatiegegevens als RUBS-gegevens vormen dan het uitgangspunt voor de RAS-procedure waarmee uiteindelijk de weegfactoren per opleidingrichting en per landsdeel zijn bepaald. Overigens worden bij (te) hoge weegfactoren op kleine aantallen cases, de weegfactoren afgekapt.

Het resultaat van de herweging staat in tabel 4.2, waarbij is opgeteld over de opleidingsrichtingen tot opleidingsclusters. Het ongewogen RUBS-bestand bevat dus gegevens zoals ze vergaard zijn, terwijl het gewogen bestand een afspiegeling vormt van de verdelingen van opleidingsrichtingen en landsdelen in de populatie. In de verdere presentatie van tabellen en cijfers zal telkens uitgegaan worden van dit gewogen bestand, aangezien deze cijf́ers representatief zijn voor Nederland. Overigens heeft de herweging alleen betrekking op schoolverlaters die hun opleiding met een diploma hebben afgesloten, daar er geen afdoende populatiegegevens met betrekking tot ongediplomeerde schoolverlaters voorhanden zijn. De populatie-aantallen zijn wel opgehoogd voor deelcertificaathouders en personen met uitsluitend een theorie-examen. De ophoogfactoren zijn gebaseerd op het RUBS-onderzoek. Daarnaast heeft een herweging voor het KMBO plaatsgevonden, uitgaande van het aantal leerlingen in het tweede leerjaar. De cijfers van het BBO zijn niet herwogen naar een landelijk representatieve verdeling van opleidingsrichting $\mathrm{x}$ landsdeel, aangezien er teveel opleidingen ontbraken om uitspraken over het gehele BBO te kunnen doen.

2. De vier landsdelen zijn als volgt samengesteld:

Noord = Groningen, Friesland en Drenthe;

Oost = Overijssel, Gelderland en Flevoland;

West = Utrecht, Noord-Holland, Zuid-Holland en Zeeland;

Zuid = Noord-Brabant en Limburg. 


\section{Wijze van dataverzameling}

\section{Algemeen}

In het Verslag Dataverzameling RUBS 1994 (Rutjes, 1995) wordt uitvoerig de wijze van dataverzameling beschreven. Kort samengevat komt het erop neer dat in principe AOB's scholen benaderen om deel te nemen aan RUBS. Indien een school voor uitsluitend de basismeting (d.w.z. de landelijke steekproef) of voor zowel basismeting als additionele meting wenst deel te nemen aan RUBS, kan dit gemeld worden aan het desbetreffende $A O B$ in de regio. In regio's waarin het $A O B$ niet participeerde is de intake verzorgd door het LDC in samenwerking met DESAN. In RUBS 1994 hebben in totaal 219 scholen geparticipeerd in het onderzoek. Nadat de school zich aangemeld heeft wordt ze voorzien van vragenlijsten en de school verstuurt deze vragenlijsten naar hun oud-leerlingen. Door de verzending van vragenlijsten door meewerkende scholen zullen oud-leerlingen eerder geneigd zijn aan een onderzoek van hun 'eigen' school mee te werken dan aan een enquête die wordt gehouden door een voor hen onpersoonlijke instantie. Bovendien is het een waarborg voor anonimiteit aangezien alleen de scholen in het bezit blijven van namen en adressen van oud-leerlingen. Het nadeel is echter dat het uitzetten van een enquête daardoor mede afhankelijk is van de bereidheid van scholen om te participeren in het RUBS-project en afhankelijk is van de kwaliteit van de administraties van scholen. Vandaar dat in toenemende mate de voorkeur wordt gegeven aan centrale verzending van de vragenlijsten. De oud-leerlingen sturen vervolgens de ingevulde vragenlijsten rechtstreeks naar de verzamelende instantie (i.c. DESAN). De antwoorden worden ingevoerd en alvorens met de analyse begonnen wordt uitvoerig gecontroleerd op fouten.

\section{Deelname onderwijsinstellingen}

Voor de onderwijsinstellingen bestonden verschillende wijzen om deel te nemen in het project. Binnen de landelijke steekproef kon men behoudens porti gratis deelnemen aan het onderzoek. Daarnaast bestond de mogelijkheid op eigen kosten te participeren in het project. Overigens is de deelname van de onderwijsinstellingen buiten de landelijke steekproef, zoals hierboven beschreven, vaak bekostigd via andere kanalen (bijdrage van het RBA of contractgelden van het $A O B$ ).

Deelname hield voor de betreffende onderwijsinstellingen in dat men na aanmelding en opgave van het aantal schoolverlaters diende zorg te dragen voor de verzending van de vragenlijsten, het aanleggen van een verzendadministratie en het verzenden van een rappel aan degenen die na verloop van tijd nog geen volledig ingevulde vragenlijst hadden geretourneerd naar DESAN. 
Om de onderwijsinstellingen behulpzaam te zijn bij deze verzending zijn door DESAN in samenspraak met het ROA een aantal documenten opgesteld, welke zowel bij de eerste zending als het rappel gelijktijdig met de vragenlijsten aan de school zijn aangeleverd. Het betreft:

a. Aandachtspunten voor de verzending;

b. Een voorbeeld brief gericht aan de schoolverlaters, welke kon worden overgenomen op briefpapier van de school;

c. Een WPR-document, waarin beknopt de verantwoordelijkheden van de school in relatie tot de WPR, specifiek in het kader van RUBS stonden beschreven.

In een aantal regio's is de verzending van de vragenlijsten uitgevoerd door het AOB. Hoewel dit in principe tot gevolg zou hebben moeten gehad dat de verzending meer gecontroleerd kon plaatsvinden is in praktijk gebleken dat het onderscheid tussen verzending door AOB's of door scholen niet direct aantoonbaar was. Dit met uitzondering van het feit dat verzending bij het $A O B$ uiteindelijk altijd wel plaats vond en er in ieder geval sprake was van een verzendadministratie.

Bij verzending door de onderwijsinstellingen is om diverse redenen een aantal instellingen afgehaakt en is in meerdere gevallen geen rappel verzonden als gevolg van het feit dat men of geen tijd meer had danwel dat men geen verzendadministratie had bijgehouden waardoor het onmogelijk was geworden een rappel te verzenden gericht aan de juiste personen. Dit heeft uiteraard gevolgen gehad voor de totale respons.

\section{De vragenlijst}

In RUBS 1994 zijn vier verschillende vragenlijsten gebruikt: één vragenlijst voor het VBO, één vragenlijst voor het KMBO en MBO, één vragenlijst voor het MAVO, HAVO en VWO en één vragenlijst voor het $\mathrm{BBO}$. Het grootste gedeelte van de vier vragenlijsten is identiek, maar soms zijn er voor een bepaald schooltype enkele vragen toegevoegd, enkele vragen weggelaten of zijn vragen iets anders gesteld. Voor zover van toepassing, zullen afwijkingen in vraagstelling in de rapportages vermeld worden. Over de volgende aspecten van de uitstroom is in RUBS informatie verzameld:

- persoonskenmerken (leeftijd, geslacht, etniciteit);

- gevolgde opleiding en vooropleiding (diplomabezit en studieduur);

- de (voornaamste) bezigheid die men op het moment van meting verricht;

- (indien van toepassing) de vervolgopleiding die men op het moment van meting volgt;

- (indien van toepassing) de opleiding in het leerlingwezen of de in-service opleiding die men op het moment van meting volgt; 
- (indien van toepassing) kenmerken van het werk, met zowel functiekenmerken (soort dienstverband, duur aanstelling, wekelijkse arbeidsduur, bruto maandloon, beroep, vereiste opleidingsniveau, vereiste opleidingsrichting) als organisatiekenmerken (organisatiegrootte, branche);

- gehanteerde vindkanalen bij het vinden van een baan;

- het volgen van aanvullende opleidingen of cursussen;

- $\quad$ aansluiting opleiding bij huidige bezigheid en een spijtvraag over de opleiding;

- aspecten in de vorige opleiding (bijvoorbeeld informatica, zelfstandig werken) die meer of minder aandacht zouden moeten krijgen.

Op verzoek van de Stichting Centrum voor Onderwijsonderzoek (SCO), verbonden aan de Universiteit van Amsterdam, is bij het rappel voor de gediplomeerde MBO-schoolverlaters en degenen die de opleiding met deelcertificaten hebben verlaten een inlegvel toegevoegd. Op dit inlegvel zijn vragen opgenomen over ondermeer:

a. HBO-opleidingsvarianten binnen het MBO;

b. Omvang van de stage(s);

c. Het beeld dat men heeft van toekomstig werk;

d. Voorlichting door de onderwijsinstelling omtrent arbeids- en opleidingsmogelijkheden;

e. Verwachtingen omtrent toekomstig inkomen.

\section{Variabelen, codering en datacleaning}

\section{Variabelen}

$\mathrm{Na}$ het vaststellen van de 4 vragenlijsten (VBO, MBO, AVO en BBO) zijn de variabelen benoemd, hun toegestane waarden vastgesteld en aangemaakt. Gewerkt wordt met logische namen waardoor koppeling met andere jaargangen RUBS vergemakkelijkt wordt en waaruit blijkt op welke vragenlijst een variabele betrekking heeft.

Naast de variabelen die gevuld worden met de antwoorden van de respondenten, worden variabelen toegevoegd voor het jaar van de enquête, sleutelgegevens die een vragenlijst kunnen identificeren en een variabele om de vragenlijsten van elkaar te kunnen onderscheiden.

Verder wordt een groot aantal nieuwe variabelen gemaakt, die gebruikt worden voor de analyses. Voorbeelden hiervan zijn de geregistreerde werkloosheid, de beroepsbevolking, vast werk, beroepsgroepen etc. De wijze van aanmaak van deze nieuwe variabelen is in 
een apart document vastgelegd ${ }^{3}$.

\section{Coderingen}

DESAN voert de codering van de opleidingen, beroepen, branches en gemeenten uit. Gehanteerd zijn de volgende classificaties:

beroep: $\quad$ CBS-beroepenclassificatie 1984

branche: $\quad$ Standaard Bedrijfsindeling 1978 (CBS)

opleiding: RUBS opleidingenclassificatie 6-digit (ROA)

gemeente: gemeentecodering CBS 1994 met toevoegingen van ROA t.b.v. buitenland

De classificaties t.b.v. beroep en branche worden door ROA verfijnd met een extra digit voor een nadere specificatie.

De codering van beroepen en branches worden steekproefsgewijs gecontroleerd door ROA. In $25 \%$ van de gevallen bleek ROA een andere keus gemaakt te hebben dan DESAN. Dit percentage komt overeen met de CBS-standaard van $75 \%$ overlap bij codering op 4-digit niveau door 2 verschillende personen.

De opleidingen- en gemeentecoderingen worden niet gecontroleerd omdat het verleden geleerd heeft dat dit vrijwel foutloos gebeurt.

\section{Datacleaning}

De oplevering van het databestand vindt plaats d.m.v. persoonlijke overdracht van DESAN aan ROA (met schriftelijke toelichting). Vanaf volgend jaar zal de overdracht worden uitgebreid met een kort, duidelijk overzicht met de uitgevoerde controles, de bevindingen en de aanpassingen.

Er worden vooraf een aantal controleregels vastgesteld. Op basis hiervan worden beslisregels gemaakt. Voor elke controle wordt geregistreerd hoeveel cases fout waren. Met behulp van controlevariabelen wordt de juiste informatie achterhaald. Gesignaleerde problemen die buiten de controleregels vallen worden, afhankelijk van het probleem, alsnog gecorrigeerd en er worden nieuwe controleregels en beslisregels voor volgend jaar geformuleerd. Essentieel bij de cleaning is de gehanteerde volgorde van controles. Is deze niet juist, dan kunnen aanpassingen overschreven worden.

3. Bijlage bij databestand RUBS 1994, Uitstroom uit het schooljaar 1992-1993, Researchcentrum voor Onderwijs en Arbeidsmarkt, 1994; 
Bij RUBS 1993 zijn eerst alle controles uitgevoerd. Toen alle bevindingen bekend waren, is de cleaning gedaan. Dit jaar is na elke controle meteen het bijbehorende cleaningprogramma gedraaid. Deze volgorde bleek veel handzamer en overzichtelijker.

Omdat dit jaar het BBO voor de eerste keer werd geênqueteerd, zijn hiervoor extra controles opgenomen. Deze vragenlijsten waren in verhouding tot de andere slecht ingevuld.

De data cleaning/controle is opgebouwd uit een aantal fasen, die hiernavolgend kort worden vermeld:

- voorbereidende werkzaamheden;

- NAW-gegevens;

- algemene controles;

- controles t.a.v. grenswaarden;

- controles betreffende de routing;

- inhoudelijke controles, als volgt samengesteld:

- anderscategorieën;

- gediplomeerden en ongediplomeerden;

- opleidingrichtingen;

- eerdere opleidingen;

- leerlingwezen/in-service opleidingen;

- betaald werk;

- scholieren;

- werkervaringsproject;

- huidig werk/beroep.

Het totale traject heeft gedraaid van 4 augustus $t / m 13$ september 1994.

De volledige lijst van controles en hun bevindingen is terug te vinden in het verslag van de data cleaning en controle RUBS 1994.

\section{Tabellen}

De gegevens die gepresenteerd worden in de tabellen hebben alleen betrekking op gediplomeerde schoolverlaters, dit wil zeggen personen met een volledig diploma, (deel)certificaathouders of met uitsluitend een theorie- of praktijkexamen. De ongediplomeerden zijn buiten beschouwing gelaten. Bij vergelijking met voorgaande cohorten, waarin wel de gegevens van ongediplomeerden waren opgenomen, zijn alleen de cijfers van gediplomeerden genomen.

Alle in de tabellen genoemde aantallen zijn gewogen naar een landelijk representatieve 
verdelingen van opleidingsrichtingen en landsdelen (behalve rapport b). De gepresenteerde aantallen zijn gewogen aantallen, die op nul decimalen zijn afgerond. De gewogen aantallen zijn dus niet gelijk aan het aantal respondenten. De ongewogen aantallen (=aantal respondenten) vormden wel de basis om té onbetrouwbare gegevens niet te presenteren. Indien de percenteerbasis minder dan 25 cases op basis van het ongewogen bestand bevat, wordt géén informatie gepresenteerd.

Genoemde aantallen en percentages in de tabellen zijn gebaseerd op het werkelijke aantal schoolverlaters dat een bepaalde vraag heeft beantwoord en niet op het aantal waarvoor de vraag bedoeld was. Voor een aantal tabellen heeft nog een nadere selectie gegolden. Deze aanvullende selecties zijn bijvoorbeeld "werkzame personen" of "beroepsbevolking". Bij de desbetreffende rapporten a tot en met $g$ (zie hoofdstuk 1) is telkens aangegeven wat de selectie c.q. noemer is. 